This document was prepared in conjunction with work accomplished under Contract No. DE-AC09-96SR18500 with the U.S. Department of Energy.

This work was prepared under an agreement with and funded by the U.S. Government. Neither the U. S. Government or its employees, nor any of its contractors, subcontractors or their employees, makes any express or implied: 1 . warranty or assumes any legal liability for the accuracy, completeness, or for the use or results of such use of any information, product, or process disclosed; or 2 . representation that such use or results of such use would not infringe privately owned rights; or 3 . endorsement or recommendation of any specifically identified commercial product, process, or service. Any views and opinions of authors expressed in this work do not necessarily state or reflect those of the United States Government, or its contractors, or subcontractors. 


\title{
High Temperature-Pressure Processing of Mixed Alanate Compounds
}

\author{
P. Berseth, J. Pittman, K. Shanahan, A. Stowe, D. Anton, R. Zidan
}

\begin{abstract}
Mixtures of light-weight elements and hydrides were investigated to increase the understanding of the chemical reactions that take place between various materials. This report details investigations we have made into mixtures that include $\mathrm{NaAlH}_{4}, \mathrm{LiAlH}_{4}$, $\mathrm{MgH}_{2}, \mathrm{Mg}_{2} \mathrm{NiH}_{4}$, alkali(ne) hydrides, and early third row transition metals (V, Cr, Mn). Experimental parameters such as stoichiometry, heat from ball milling versus hand milling, and varying the temperature of high pressure molten state processing were studied to examine the effects of these parameters on the reactions of the complex metal hydrides.
\end{abstract}

Keywords: A. alloys, A. intermetallic compounds, B. chemical synthesis, C. X-ray diffraction.

\section{Introduction}

Solid state materials which store hydrogen with high gravimetric and volumetric densities are needed to develop a hydrogen economy for transportation applications. To this end, hydrogen containing solids of the light-weight elements are under intensive investigation.[1-6] Desirable materials properties include a high weight percent hydrogen (ideally $9 \geq \mathrm{wt} \%$ ), rapid release and uptake of $\mathrm{H}_{2}$ at pressures of $100 \mathrm{~atm}$ or less, and operation at fuel cell compatible temperatures $\left(\mathrm{T} \leq 160^{\circ} \mathrm{C}\right)$. This combination of properties is challenging to achieve in one material, and while there are a variety of materials that exhibit one or more of these properties, no material to date meets all of the criteria. For instance, magnesium is abundant, relatively inexpensive, and $\mathrm{MgH}_{2}$ has a large weight percent hydrogen ( $7.9 \%)$ but the temperature for hydrogen evolution is about $300{ }^{\circ} \mathrm{C}$, and the kinetics of hydrogenation are too slow.[7] Titanium catalyzed $\mathrm{NaAlH}_{4}$ is reversible and releases hydrogen at acceptable temperatures, but the kinetics are slow and the weight percent is mediocre (5.6\%).[8-10] One method of tailoring 
properties is to combine two or more materials to create a new material with intermediate properties. One interesting example of this is $\mathrm{Mg}_{2} \mathrm{NiH}_{4}$, where the mixed metal hydride has a lower dehydrogenation temperature $\left(\sim 250^{\circ} \mathrm{C}\right.$ vs $300{ }^{\circ} \mathrm{C}$ for $\left.\mathrm{MgH}_{2}\right)$ and better kinetics of hydrogenation. Researchers have investigated the effect of combining $\mathrm{Mg}_{2} \mathrm{NiH}_{4}$ with a variety of materials, e.g. transition metal oxides, $\mathrm{Pd}$, and excess $\mathrm{MgH}_{2}$, in order to improve properties.[11]

Even with the constraint of focusing on the light-weight elements, there is a wide variety of mixtures to be investigated with the goals of understanding the chemical reactions that take place between various materials, and possibly creating a new material with improved properties. This report details investigations we have made into mixtures that include $\mathrm{NaAlH}_{4}, \mathrm{LiAlH}_{4}, \mathrm{MgH}_{2}, \mathrm{Mg}_{2} \mathrm{NiH}_{4}$, alkali(ne) hydrides, and early third row transition metals $(\mathrm{V}, \mathrm{Cr}, \mathrm{Mn})$, where $\mathrm{V}$ is used in the hydrided form to compare the effect of transition metal hydride vs. bare transition metal.

\section{Experimental}

Mixtures were made by dry mixing in a Spex 8000 ball mill. The vial volume is $65 \mathrm{~mL}$, and two $12.7 \mathrm{~mm}$ and four $6.4 \mathrm{~mm}$ balls was used for mixing. Mixture components and balls were loaded into ball mill vials under an inert atmosphere (Argon gas). Samples were typically milled for 60 minutes. Cold ball milling was performed by chilling the vial on dry ice for 5-10 minutes, then ball milling in 10 minute increments with chilling of the vial between each milling cycle. Hand milling was performed with an agate mortar and pestle under Argon atmosphere. X-ray diffraction (XRD) samples were pressed onto quartz plates, and sealed with a thin film of polyethylene under Argon atmosphere, then transferred to the diffractometer for analysis using $\mathrm{Cu} \mathrm{K}_{\alpha}$ radiation. 
Molten state processing (MSP), an SRNL patented technique, was used to heat ball milled mixtures under high hydrogen gas pressure (usually $4500 \mathrm{psi}$ ) in order to synthesize possible new phases.[12,13] The premise is that the high $\mathrm{H}_{2}$ pressure will favor the formation of products with high hydrogen content, following Le Châtelier's principle. Vanadium forms hydrides rather easily, so vanadium powder was heated under vacuum/hydrogen cycles to create $\mathrm{VH}_{0.81}$ for use in these experiments.[14]

\section{Results and Discussion}

Table 1 provides a comprehensive list of the various mixtures that were investigated in this study. The mixtures we have explored include $\mathrm{NaAlH}_{4}, \mathrm{LiAlH}_{4}$, $\mathrm{MgH}_{2}$ and $\mathrm{Mg}_{2} \mathrm{NiH}_{4}$ as the primary materials, with addition of alkali(ne) hydrides, and/or early third row transition metals $(\mathrm{V}, \mathrm{Cr}, \mathrm{Mn})$ and occasionally $\mathrm{TiCl}_{3}$. The metals $\mathrm{Cr}$ and Mn were chosen because they do not easily form hydrides under the conditions of our experiment, so the effect of a transition metal in "metal" form could be examined. Vanadium, immediately to the left of $\mathrm{Cr}$ on the periodic table, does form a hydride so $\mathrm{VH}_{0.81}$ was used to explore the difference in chemical reactions of a transition metal versus a transition metal hydride additive. Experimental parameters such as stoichiometry, temperature of ball milling, use of hand milling, and temperature of MSP were varied to study the effects of these parameters on the products. Starting materials are abbreviated SM for brevity in the table, and this indicates that all of the starting materials are seen in the XRD pattern of the indicated reaction step.

\section{3a. Mixtures of alanates and transition metals:}

\section{Mixtures with Cr metal:}


The quaternary mixture, which has $\mathrm{NaAlH}_{4}, \mathrm{LiAlH}_{4}$, and $\mathrm{MgH}_{2}$ mixed with $\mathrm{Cr}$ was first investigated with a simple 1:1:1:1 mixture. This treatment produced starting materials and aluminum. Based on the fact that the binary mixture of $\mathrm{LiAlH}_{4}$ and various transition metals yields aluminum and starting materials, we conclude that some of the $\mathrm{LiAlH}_{4}$ has decomposed with ball milling, which is known to occur.[15] The decomposition reaction is expected to take place as shown below in equation 1 .

$$
3 \mathrm{LiAlH}_{4} \rightarrow \mathrm{Li}_{3} \mathrm{AlH}_{6}+2 \mathrm{Al}+3 \mathrm{H}_{2}
$$

Note that only the $\mathrm{Al}$ product is seen in the $\mathrm{XRD}$ pattern, any $\mathrm{Li}_{3} \mathrm{AlH}_{6}$ produced does not show up in the XRD pattern, which is not uncommon as many of the expected $\mathrm{Li}$ containing species are not seen in XRD patterns of the products in this study. There are several possible reasons for the lack of XRD signal, including x-ray absorption by heavier elements, formation of nanoparticles, or formation of an amorphous phase.

When the mixture is further reacted with MSP conditions at $170{ }^{\circ} \mathrm{C}$, the reaction yields mixed metal products as follows (XRD scans are qualitative, not quantitative, so this is not a balanced reaction equation, rather it is a list of products formed):

$$
\begin{array}{r}
\mathrm{LiAlH}_{4}+\mathrm{NaAlH}_{4}+\mathrm{MgH}_{2}+\mathrm{Cr}+\mathrm{Al} \rightarrow\left(\mathrm{MSP}, 170{ }^{\circ} \mathrm{C}\right) \rightarrow \\
\mathrm{LiNa}_{2} \mathrm{AlH}_{6}+\mathrm{NaMgH}_{3}+\mathrm{NaH}+\mathrm{Al}+\mathrm{MgH}_{2}+\mathrm{Cr}
\end{array}
$$

One can make assumptions about the reactions that took place to form this mix of products.

$$
\begin{aligned}
& \mathrm{LiAlH}_{4}+2 \mathrm{NaAlH}_{4} \rightarrow \mathrm{Na}_{2} \mathrm{LiAlH}_{6}+2 \mathrm{Al}+3 \mathrm{H}_{2} \\
& \mathrm{NaAlH}_{4}+\mathrm{MgH}_{2} \rightarrow \mathrm{NaMgH}_{3}+\mathrm{Al}+3 / 2 \mathrm{H}_{2}
\end{aligned}
$$

The product mixture contains $\mathrm{NaH}$ as well, which likely comes from the partial decomposition of $\mathrm{Na}_{2} \mathrm{LiAlH}_{6}$, as shown in reaction 5 below. 


$$
\mathrm{Na}_{2} \mathrm{LiAlH}_{6} \rightarrow 2 \mathrm{NaH}+\mathrm{LiH}+\mathrm{Al}+3 / 2 \mathrm{H}_{2}
$$

No evidence of $\mathrm{LiH}$ is seen in the XRD pattern, though it is likely present unless the $\mathrm{NaH}$ is formed from the decomposition of a possible $\mathrm{Na}_{3} \mathrm{AlH}_{6}$ reaction intermediate.

The $\mathrm{NaH}$ product is seen with quaternary mixtures containing $\mathrm{Cr}$ or $\mathrm{Mn}$, which indicates that transition metals, when employed as metals, assist the partial decomposition of the alanates. When $\mathrm{VH}_{0.81}$ is used as the quaternary element, the $\mathrm{NaH}$ is not seen. Additionally, with the $\mathrm{VH}_{0.81}$ reactant, $\mathrm{LiAlH}_{4}$ remains in the product mixture, while it does not for either $\mathrm{Cr}$ or $\mathrm{Mn}$. This suggests that the $\mathrm{VH}_{0.81}$ is not catalyzing the decomposition of the alanates relative to the $\mathrm{Cr}$ and $\mathrm{Mn}$ reactants, which are in the elemental state. The XRD patterns of the MSP product for mixtures containing $\mathrm{Cr}$ and $\mathrm{VH}_{0.81}$ are shown in Figures 1 and 2. The XRD patterns do not show evidence of $\mathrm{LiH}$ formation, but because the Li containing products, especially in small quantities, are apt not to show up in $\mathrm{XRD}$, the possibility that $\mathrm{LiH}$ is also present is not ruled out as the scattering from $\mathrm{LiH}$ is relatively weak compared to the other components of the sample.

These $\mathrm{Cr}$ mixtures were explored further by varying the ratio of starting materials away from the simple 1:1:1:1 mixtures that had been explored for the other transition metals. The $\mathrm{Cr}$ and the $\mathrm{MgH}_{2}$ mol ratios were varied to see if this would change the reaction. When the Cr content was doubled, regardless of the $\mathrm{MgH}_{2}$ content, ball milling formed starting materials and $\mathrm{Al}$. When the mol ratio of $\mathrm{Cr}$ is increased to 4, ball milling alone causes the $\mathrm{LiAlH}_{4}$ to fully decompose to $\mathrm{Li}_{3} \mathrm{AlH}_{6}$. This is a confirmation that the presence of excess $\mathrm{Cr}$ catalyzes the decomposition of $\mathrm{LiAlH}_{4}$, which is expected from a transition metal. 
The temperature of ball milling is another experimental parameter that was varied. A typical 60 minute ball milling reaction creates enough heat to warm the vials to approximately $60^{\circ} \mathrm{C}$. In order to separate the effect of mechanical mixing from the effect of heating the mixture during mixing, the 1:1:1:1 Cr mixture was ball milled "cold" by cooling the vial every 10 minutes for a total of 60 minutes of milling; the vials did not exceed room temperature with this method. The cold ball milling prevented the decomposition of $\mathrm{LiAlH}_{4}$ and only the starting materials were seen in the XRD pattern, where regular ball milling shows an XRD pattern with starting material and aluminum. The cold ball milled mixture, and the regular ball milled mixture, were further reacted under MSP conditions at a low temperature of $60^{\circ} \mathrm{C}$ (usually done at $170{ }^{\circ} \mathrm{C}$ or higher). The low temperature MSP yields $\mathrm{SM}, \mathrm{Al}$, and $\mathrm{Li}_{3} \mathrm{AlH}_{6}$ regardless of ball milling conditions. Note that in this case the $\mathrm{Li}_{3} \mathrm{AlH}_{6}$ is present in the XRD pattern. The Al peak is much more intense after the MSP step versus after the ball milling step, so presumably the 3 hour heating provides energy for crystallization of the products allowing $\mathrm{Li}_{3} \mathrm{AlH}_{6}$ to be seen, and/or the quantity of products has increased with heat, to a level of $\mathrm{Li}_{3} \mathrm{AlH}_{6}$ detectable by XRD. Mixtures with Mn metal:

The quaternary mixture of both alanates, $\mathrm{MgH}_{2}$ and $\mathrm{Mn}$ is interesting in that it yields $\mathrm{MnH}_{0.07}$ with just ball milling, in addition to the non-Mn starting materials and $\mathrm{Al}$. The $\mathrm{H}$ is assumed to originate with $\mathrm{LiAlH}_{4}$ that decomposes with ball milling. When this mixture is heated for MSP, the $\mathrm{MnH}_{0.07}$ decomposes leaving $\mathrm{Mn}$, in addition to $\mathrm{MgH}_{2}$, Al, $\mathrm{Na}_{2} \mathrm{LiAlH}_{6}, \mathrm{NaMgH}_{3}$, and $\mathrm{NaH}$.

Mixtures with $\mathrm{VH}_{0.81}$ : 
The quaternary mixture of $\mathrm{NaAlH}_{4}: \mathrm{LiAlH}_{4}: \mathrm{MgH}_{2}: \mathrm{VH}_{0.81}$ 1:1:1:1 forms starting materials and $\mathrm{Al}$ with ball milling. The MSP reaction of this mixture at $170{ }^{\circ} \mathrm{C}$ results in the formation of starting materials $\mathrm{LiAlH}_{4}, \mathrm{MgH}_{2}$ and $\mathrm{VH}_{0.81}$ in addition to $\mathrm{Al}$, $\mathrm{Na}_{2} \mathrm{LiAlH}_{6}$ and $\mathrm{NaMgH}_{3}$.

There is clearly a difference in behavior between the Mn and Cr metal samples, and the $\mathrm{VH}_{0.81}$ hydride samples. We see that the transition metals assist in the partial decomposition of the alanates.

\section{3b. Mixtures of alanates and $\mathrm{Mg}_{2} \mathrm{NiH}_{4}$ :}

The mixed metal hydride $\mathrm{Mg}_{2} \mathrm{NiH}_{4}$ contains the transition metal $\mathrm{Ni}$, which assists in the decomposition of this material relative to $\mathrm{MgH}_{2}$, much as the transition metals assist in the decomposition of the alanates. The $\mathrm{Mg}_{2} \mathrm{NiH}_{4}$ was ball milled with 1) $\mathrm{LiAlH}_{4}$, 2) $\mathrm{NaAlH}_{4}$, and 3) $\mathrm{NaAlH}_{4}$ with $4 \mathrm{~mol} \% \mathrm{TiCl}_{3}$ to explore the affect of the $\mathrm{Ni}$ component on the alanate materials. The mixture with $\mathrm{LiAlH}_{4}$ results in the starting $\mathrm{Mg}$ compound completely decomposing with ball milling to form 4 products: $\mathrm{MgH}_{2}, \mathrm{Mg}_{2} \mathrm{NiH}$, and $\mathrm{Mg}_{2} \mathrm{NiH}_{0.3}$ and $\mathrm{Al}_{1.1} \mathrm{Ni}_{0.9}$. Apparently the $\mathrm{Mg}_{2} \mathrm{NiH}_{4}$ has partially disproportionated to $\mathrm{MgH}_{2}$ and $\mathrm{Ni}$, and presumably the $\mathrm{Ni}$ has catalyzed the decomposition of $\mathrm{LiAlH}_{4}$ resulting in $\mathrm{LiH}$ and $\mathrm{Al}$ formation, where the $\mathrm{Ni}$ and $\mathrm{Al}$ go on to form the $\mathrm{Al}_{1.1} \mathrm{Ni}_{0.9}$ alloy.

The ball milled mixture with $\mathrm{NaAlH}_{4}$ has only one product in common with the $\mathrm{LiAlH}_{4}$ mixture, and that is $\mathrm{Mg}_{2} \mathrm{NiH}_{0.3}$. There are also starting materials present after ball milling, as well as the previously known mixed metal $\mathrm{NaMgH}_{3}$. When $4 \mathrm{~mol} \% \mathrm{TiCl}_{3}$ is added in addition to $\mathrm{NaAlH}_{4}, \mathrm{Mg}_{2} \mathrm{NiH}_{0.26}$ is formed along with $\mathrm{NaMgH}_{3}$ and $\mathrm{Al}$, and starting materials remain. A likely reaction path is that Ti catalyzes the dehydrogenation of $\mathrm{NaAlH}_{4}$ in the ball mill vial, and the $\mathrm{NaH}$ formed reacts with $\mathrm{MgH}_{2}$ to form the 
$\mathrm{NaMgH}_{3}$. If the mixture with $\mathrm{TiCl}_{3}$ is hand ground in a mortar and pestle (much lower energy than a ball mill) the mixed metal hydride $\mathrm{NaMgH}_{3}$ does not form, which suggests that the energy and/or heat associated with ball milling is required for this reaction to take place.

\section{3c. Mixtures of $\mathrm{LiAlH}_{4}$ and binary hydrides:}

Mixtures of $\mathrm{LiAlH}_{4}, 4 \mathrm{~mol} \% \mathrm{Ti}$, and the binary hydrides 1) $\mathrm{KH}$, 2) $\mathrm{MgH}_{2}$ and 3) $\mathrm{CaH}_{2}$ were investigated. Ball milling the mixture with $\mathrm{KH}$ produced two ion exchange compounds, $\mathrm{KAlH}_{4}$ and $\mathrm{K}_{3} \mathrm{AlH}_{6}$, and left unreacted $\mathrm{LiAlH}_{4}$ which continued the ion exchange with MSP. Ball milling with $\mathrm{MgH}_{2}$ causes the $\mathrm{LiAlH}_{4}$ to completely decompose to form $\mathrm{Li}_{3} \mathrm{AlH}_{6}$ which is a good indicator that the $\mathrm{MgH}_{2}$ has a catalytic effect on $\mathrm{LiAlH}_{4}$ decomposition. The combination containing $\mathrm{CaH}_{2}$ produced starting materials, $\mathrm{Li}_{3} \mathrm{AlH}_{6}$, and $\mathrm{Al}$ with ball milling, indicating that the $\mathrm{LiAlH}_{4}$ partially decomposes while the $\mathrm{CaH}_{2}$ does not react. When heated with MSP, this mixture forms $\mathrm{CaH}_{2}, \mathrm{Al}, \mathrm{LiCl}$ and $\mathrm{LiH}$, which are expected products from the decomposition of $\mathrm{LiAlH}_{4}$ and reaction of the chloride from $\mathrm{TiCl}_{3}$ with $\mathrm{Li}$ decomposition products.

\section{3d. Mixtures of $\mathrm{Mg}_{2} \mathrm{NiH}_{4}$ and binary hydrides:}

The mixed metal compound $\mathrm{Mg}_{2} \mathrm{NiH}_{4}$ was ball milled with 1) $\mathrm{LiH}$ and 2)NaH. In both cases, the mixtures yielded starting materials, $\mathrm{MgH}_{2}$, and $\mathrm{Mg}_{2} \mathrm{NiH}_{2.6}$, and in the case of $\mathrm{LiH}$, some $\mathrm{Mg}$ was present as well.

\section{Conclusion}

A wide variety of hydride mixtures, with and without light transition metal additives, were investigated. This work provides insight into the chemical reactions that take place between four hydride materials that are possible contenders for transportation 
applications, if the systems can be fine tuned to overcome temperature, kinetic or weight percent limitations.

The addition of transition metal elements to $\mathrm{NaAlH}_{4}$ does not create mixed metal alanates - no reaction is seen with ball milling, and MSP generally produces a decomposition product, $\mathrm{Na}_{3} \mathrm{AlH}_{6}$. However, the addition of elements or other hydrides destabilizes $\mathrm{LiAlH}_{4}$ - with the elements $\mathrm{Al}$ is seen in the XRD pattern, while mixtures with binary hydrides produce the hexahydride, $\mathrm{Li}_{3} \mathrm{AlH}_{6}$ (or $\mathrm{K}_{3} \mathrm{AlH}_{6}$ in the case of $\mathrm{KH}$ ).

$\mathrm{NaAlH}_{4}$ in combination with $\mathrm{Mg}$ materials often produces $\mathrm{NaMgH}_{3}$. When the $\mathrm{Mg}$ compound used is $\mathrm{Mg}_{2} \mathrm{NiH}_{4}, \mathrm{NaMgH}_{3}$ forms with just ball milling. Mixtures with $\mathrm{MgH}_{2}$ do not form the mixed metal hydride unless heated above $60^{\circ} \mathrm{C}$ in the MSP step. Two explanations for this are likely, first that the presence of Ni catalyzes the decomposition of $\mathrm{NaAlH}_{4}$, and second that $\mathrm{Mg}_{2} \mathrm{NiH}_{4}$ is less kinetically stable, and therefore more reactive, than $\mathrm{MgH}_{2}$. The temperature effect is seen in the hexahydride product as well, but for a different reason. Mixtures containing $\mathrm{LiAlH}_{4}$ and $\mathrm{NaAlH}_{4}$ form mixed metal $\mathrm{Na}_{2} \mathrm{LiAlH}_{6}$ with MSP of $170{ }^{\circ} \mathrm{C}$ or higher, while $\mathrm{Li}_{3} \mathrm{AlH}_{6}$ is formed with MSP at $60{ }^{\circ} \mathrm{C}$ rather than the mixed metal product. The difference in products is likely due to the fact that solid state diffusion is relatively slow and $\mathrm{LiAlH}_{4}$ melts at $125^{\circ} \mathrm{C}$ so the higher temperature reactions have one molten component, greatly aiding diffusion.

Quaternary mixtures lead to known mixed metal products $\mathrm{Na}_{2} \mathrm{LiAlH}_{6}$ and $\mathrm{NaMgH}_{3}$. When the transition metal additive is $\mathrm{Cr}$ or $\mathrm{Mn}$, no residual $\mathrm{LiAlH}_{4}$ reactant remains but residual $\mathrm{MgH}_{2}$ does, while the transition metal additive $\mathrm{VH}_{0.81}$ leaves $\mathrm{LiAlH}_{4}$ reactant remaining in the product mixture. This indicates that the limiting $\mathrm{NaAlH}_{4}$ 
reagent preferentially reacts with $\mathrm{LiAlH}_{4}$ in the presence of $\mathrm{Cr}$ and $\mathrm{Mn}$, which are active transition metal catalysts, relative to $\mathrm{VH}_{0.81}$.

\section{Acknowledgement}

We would like to acknowledge the assistance and helpful discussions of Art Jurgensen in the matter of XRD data collection and interpretation and of Martin Scott for laboratory support. Funding was provided by DOE contract \# EB4202000.

\section{References}

1. Tang, X., et al., Hydrogen storage properties of Na-Li-Mg-Al-H complex hydrides. Journal of Alloys and Compounds. In Press, Corrected Proof: p. 366.

2. Fakioglu, E., Y. Yurum, and T. Nejat Veziroglu, A review of hydrogen storage systems based on boron and its compounds. International Journal of Hydrogen Energy, 2004. 29(13): p. 1371-1376.

3. Chandra, D.R., James J.; Chellappa, Raja, Metal Hydrides for Vehicular Applications: The State of the Art. Journal of the Minerals, Metals \& Materials Society, 2006. 58(2): p. 26-32.

4. Vajo, J.J., S.L. Skeith, and F. Mertens, Reversible Storage of Hydrogen in Destabilized LiBH4. J. Phys. Chem. B, 2005. 109(9): p. 3719-3722.

5. Orimo, S., et al., Dehydriding and rehydriding reactions of LiBH4. Journal of Alloys and Compounds, 2005. 404-406: p. 427-430.

6. Ritter, J.A., et al., Implementing a hydrogen economy. Materials Today, 2003. 6(9): p. 18-23.

7. de Rango, P., et al., Nanostructured magnesium hydride for pilot tank development. Journal of Alloys and Compounds. In Press, Corrected Proof.

8. Wang, J., et al., Synergistic effects of co-dopants on the dehydrogenation kinetics of sodium aluminum hydride. Journal of Alloys and Compounds, 2005. 391(1-2): p. 245-255.

9. Anton, D.L., Hydrogen desorption kinetics in transition metal modified NaAlH4. Journal of Alloys and Compounds, 2003. 356-357: p. 400-404.

10. Fichtner, M., et al., Nanocrystalline alanates--Phase transformations, and catalysts. Journal of Alloys and Compounds, 2005. 404-406: p. 732-737.

11. Sakintuna, B., F. Lamari-Darkrim, and M. Hirscher, Metal hydride materials for solid hydrogen storage: A review. International Journal of Hydrogen Energy, 2007. 32(9): p. 1121-1140.

12. Zidan, R., Complex hydrides for hydrogen storage, USPO, Editor. 2003, Washington Savannah River Company LLC: United States.

13. Zidan, R.S., K.; Anton, D.; Jurgensen, A.; Pittman, J. Development and Characterization of Novel Complex Hydrides- Synthesized via Molten State 
Processing. in Material Research Society, Fall 2005. 2005. Boston: Materials Research Society.

14. Golubkov, A.N. and A.A. Yukhimchuk, Synthesis of the dihydride phase of vanadium. Journal of Alloys and Compounds, 2005. 404-406: p. 35-37.

15. Balema, V.P., et al., Titanium catalyzed solid-state transformations in LiAlH4 during high-energy ball-milling. Journal of Alloys and Compounds, 2001. 329(1-2): p. 108-114. 
Table 1: Mixtures of materials investigated.

\begin{tabular}{|c|c|c|c|c|c|}
\hline Compounds & $\begin{array}{c}\text { mol } \\
\text { ratios }\end{array}$ & prep cond & $\begin{array}{l}\text { MSP cond } \\
\left({ }^{\circ} \mathrm{C}-p s i \mathrm{H}_{2-}\right. \\
\text { time })\end{array}$ & BM Results & MSP Results \\
\hline \multirow[b]{2}{*}{$\mathrm{NaAlH}_{4}: \mathrm{LiAlH}_{4}: \mathrm{Cr}$} & \multirow[b]{2}{*}{ 1:1:1 } & \multirow[b]{2}{*}{ Spex BM 60 min } & \multirow[b]{2}{*}{$170-4500-2 \mathrm{~h}$} & \multirow[b]{2}{*}{$\mathrm{SM}+\mathrm{Al}$} & $\mathrm{NaAlH}_{4}, \mathrm{Cr}, \mathrm{Na}_{2} \mathrm{LiAlH}_{6}$ \\
\hline & & & & & $\mathrm{Al}, \mathrm{NaH}$ \\
\hline \multirow[b]{2}{*}{$\mathrm{NaAlH}_{4}: \mathrm{LiAlH}_{4}: \mathrm{Mn}$} & \multirow[b]{2}{*}{ 1:1:1 } & \multirow[b]{2}{*}{ Spex BM 60 min } & \multirow[b]{2}{*}{$190-4500-2 \mathrm{~h}$} & \multirow[b]{2}{*}{$\mathrm{SM}+\mathrm{Al}$} & $\mathrm{Mn}, \mathrm{Na}_{2} \mathrm{LiAlH}_{6}, \mathrm{Al}, \mathrm{NaH}$ \\
\hline & & & & & \\
\hline \multirow[b]{2}{*}{$\mathrm{NaAlH}_{4}: \mathrm{LiAlH}_{4}: \mathrm{Mn}$} & \multirow[b]{2}{*}{ 1:1:1 } & \multirow[b]{2}{*}{ Spex BM 60 min } & \multirow[b]{2}{*}{$170-4500-2 \mathrm{~h}$} & \multirow[b]{2}{*}{$\mathrm{SM}+\mathrm{Al}$} & $\mathrm{Mn}, \mathrm{Na}_{2} \mathrm{LiAlH}_{6}, \mathrm{Al}, \mathrm{NaH}$ \\
\hline & & & & & \\
\hline \multirow[b]{2}{*}{$\mathrm{NaAlH}_{4}: \mathrm{LiAlH}_{4}: \mathrm{MgH}_{2}: \mathrm{VH}_{0.81}$} & \multirow[b]{2}{*}{ 1:1:1:1 } & \multirow[b]{2}{*}{ Spex BM 60 min } & \multirow[b]{2}{*}{$170-4500-2 \mathrm{~h}$} & \multirow[b]{2}{*}{$\mathrm{SM}+\mathrm{Al}$} & $\mathrm{LiAlH}_{4}: \mathrm{MgH}_{2}: \mathrm{VH}_{0.81}, \mathrm{Al}$ \\
\hline & & & & & $\mathrm{Na}_{2} \mathrm{LiAlH}_{6}, \mathrm{NaMgH}_{3}$ \\
\hline \multirow[b]{2}{*}{$\mathrm{NaAlH}_{4}: \mathrm{LiAlH}_{4}: \mathrm{MgH}_{2}: \mathrm{Cr}$} & \multirow[b]{2}{*}{ 1:1:1:1 } & \multirow[b]{2}{*}{ Spex BM 60 min } & \multirow[b]{2}{*}{$170-4500-2 \mathrm{~h}$} & \multirow[b]{2}{*}{$\mathrm{SM}+\mathrm{Al}$} & $\mathrm{MgH}_{2}, \mathrm{Cr}, \mathrm{Al}, \mathrm{Na}_{2} \mathrm{LiAlH}_{6}$ \\
\hline & & & & & $\mathrm{NaMgH}_{3}, \mathrm{NaH}$ \\
\hline $\mathrm{NaAlH}_{4}: \mathrm{LiAlH}_{4}: \mathrm{MgH}_{2}: \mathrm{Cr}$ & 1:1:1:1 & Spex BM 60 min & $60-4500-3 \mathrm{~h}$ & $\mathrm{SM}+\mathrm{Al}$ & $\mathrm{SM}+\mathrm{Al}, \mathrm{Li}_{3} \mathrm{AlH}_{6}$ \\
\hline $\mathrm{NaAlH}_{4}: \mathrm{LiAlH}_{4}: \mathrm{MgH}_{2}: \mathrm{Cr}$ & 1:1:1:1 & cold ball mill & $60-4500-3 \mathrm{~h}$ & $\mathrm{SM}$ & $\mathrm{SM}+\mathrm{Al}, \mathrm{Li}_{3} \mathrm{AlH}_{6}$ \\
\hline $\mathrm{NaAlH}_{4}: \mathrm{LiAlH}_{4}: \mathrm{MgH}_{2}: \mathrm{Cr}$ & $1: 1: 1: 2$ & Spex BM 60 min & & $\mathrm{SM}+\mathrm{Al}$ & \\
\hline \multirow[b]{2}{*}{$\mathrm{NaAlH}_{4}: \mathrm{LiAlH}_{4}: \mathrm{MgH}_{2}: \mathrm{Cr}$} & & & & $\mathrm{NaAlH}_{4}, \mathrm{MgH}_{2}, \mathrm{Cr}$ & \\
\hline & 1:1:1:4 & Spex BM 60 min & & $\mathrm{Al}, \mathrm{Li}_{3} \mathrm{AlH}_{6}$ & \\
\hline $\mathrm{NaAlH}_{4}: \mathrm{LiAlH}_{4}: \mathrm{MgH}_{2}: \mathrm{Cr}$ & $1: 1: 2: 2$ & Spex BM 60 min & & $\mathrm{SM}+\mathrm{Al}$ & \\
\hline $\mathrm{NaAlH}_{4}: \mathrm{LiAlH}_{4}: \mathrm{MgH}_{2}: \mathrm{Cr}$ & $1: 1: 2: 1$ & Spex BM 60 min & & $\mathrm{SM}+\mathrm{Al}$ & \\
\hline & & & & $\mathrm{NaAlH}_{4}: \mathrm{LiAlH}_{4}: \mathrm{MgH}_{2}$ & $\mathrm{MgH}_{2}, \mathrm{Mn}, \mathrm{Na}_{2} \mathrm{LiAlH}_{6}$ \\
\hline $\mathrm{NaAlH}_{4}: \mathrm{LiAlH}_{4}: \mathrm{MgH}_{2}: \mathrm{Mn}$ & 1:1:1:1 & Spex BM 60 min & $170-4500-2 \mathrm{~h}$ & $\mathrm{MnH}_{0.07}, \mathrm{Al}$ & $\mathrm{NaMgH}_{3}, \mathrm{Al}, \mathrm{NaH}$ \\
\hline $\mathrm{NaAlH}_{4}: \mathrm{VH}_{0.81}$ & $1: 1$ & Spex BM 60 min & & $\mathrm{n} / \mathrm{a}-$ outgasses & \\
\hline $\mathrm{NaAlH}_{4}: \mathrm{Cr}$ & $1: 1$ & Spex BM 60 min & $190-4500-2 \mathrm{~h}$ & SM & $\mathrm{SM}, \mathrm{Na}_{3} \mathrm{AlH}_{6}$ \\
\hline $\mathrm{NaAlH}_{4}: \mathrm{Mn}$ & $1: 1$ & Spex BM 60 min & $190-4500-2 \mathrm{~h}$ & SM & $\mathrm{SM}, \mathrm{Na}_{3} \mathrm{AlH}_{6}$ \\
\hline $\mathrm{LiAlH}_{4}: \mathrm{Cr}$ & $1: 1$ & Spex BM 60 min & $170-4500-2 \mathrm{~h}$ & $\mathrm{SM}+\mathrm{Al}$ & $\mathrm{SM}+\mathrm{Al}, \mathrm{L}_{\mathrm{i} 3} \mathrm{AlH}_{6}$ \\
\hline $\mathrm{LiAlH}_{4}: \mathrm{Mn}$ & $1: 1$ & Spex BM 60 min & $170-4500-2 \mathrm{~h}$ & $\mathrm{SM}+\mathrm{Al}$ & $\mathrm{Mn}, \mathrm{Al}$ \\
\hline & & & & $\mathrm{LiAlH}_{4}, \mathrm{KAlH}_{4}$ & \\
\hline $\mathrm{LiAlH}_{4}: \mathrm{KH}: \mathrm{TiCl}_{3}$ & $1: 2: .04$ & $\mathrm{BM} 40 \mathrm{~min}$ & & $\mathrm{~K}_{3} \mathrm{AlH}_{6}$ & $\mathrm{LiAlH}_{4}, \mathrm{KAlH}_{4}, \mathrm{~K}_{3} \mathrm{AlH}_{6}, \mathrm{KCl}$, \\
\hline & & & & $\mathrm{MgH}_{2}, \mathrm{Li}_{3} \mathrm{AlH}_{6}$ & \\
\hline $\mathrm{LiAlH}_{4}: \mathrm{MgH}_{2}: \mathrm{TiCl}_{3}$ & 1:1:.04 & BM 40 min & & $\mathrm{Al}, \mathrm{LiCl}, \mathrm{Mg}$ & $\mathrm{MgH}_{2}, \mathrm{Al}, \mathrm{LiCl}$ \\
\hline $\mathrm{LiAlH}_{4}: \mathrm{CaH}_{2}: \mathrm{TiCl}_{3}$ & 1:1:.04 & $\mathrm{BM} 40 \mathrm{~min}$ & & $\mathrm{SM}, \mathrm{Li}_{3} \mathrm{AlH}_{6}, \mathrm{Al}$ & $\mathrm{CaH}_{2}, \mathrm{Al}, \mathrm{LiCl}, \mathrm{LiH}$ \\
\hline & & & & $\mathrm{MgH}_{2}, \mathrm{Mg}_{2} \mathrm{NiH}$ & \\
\hline $\mathrm{LiAlH}_{4}: \mathrm{Mg}_{2} \mathrm{NiH}_{4}$ & $1: 1$ & & & $\mathrm{Mg}_{2} \mathrm{NiH}_{0.3}, \mathrm{Al}_{1.1} \mathrm{Ni}_{0.8}$ & \\
\hline & & & & $\mathrm{SM}, \mathrm{NaMgH}_{3}$ & \\
\hline $\mathrm{NaAlH}_{4}: \mathrm{Mg}_{2} \mathrm{NiH}_{4}$ & $1: 1$ & & & $\mathrm{Mg}_{2} \mathrm{NiH}_{0.3}$ & \\
\hline & & & & $\mathrm{SM}, \mathrm{MgH}_{2}$ & \\
\hline $\mathrm{NaAlH}_{4}: \mathrm{Mg}_{2} \mathrm{NiH}_{4}: \mathrm{TiC}_{13}$ & $1: 1: .04$ & mortar pestle & & $\mathrm{Mg}_{2} \mathrm{NiH}_{0.3}$ & \\
\hline & & & & $\mathrm{SM}, \mathrm{Al}, \mathrm{NaMgH}_{3}$ & \\
\hline $\mathrm{NaAlH}_{4}: \mathrm{Mg}_{2} \mathrm{NiH}_{4}: \mathrm{TiCl}_{3}$ & 1:1:.04 & BM 40 min & & $\mathrm{Mg}_{2} \mathrm{NiH}_{0.26}$ & \\
\hline $\mathrm{Mg}_{2} \mathrm{NiH}_{4}: \mathrm{NaH}$ & $1: 1.2$ & mortar pestle & & $\mathrm{SM}, \mathrm{MgH}_{2}, \mathrm{Mg}_{2} \mathrm{NiH}_{26}$ & \\
\hline $\mathrm{Mg}_{2} \mathrm{NiH}_{4}: \mathrm{LiH}$ & 1:9.9 & $\mathrm{BM} 40 \mathrm{~min}$ & & $\mathrm{SM}, \mathrm{MgH}_{2}, \mathrm{Mg}_{2} \mathrm{NiH}_{26}$ & \\
\hline
\end{tabular}


Figure 1: $\mathrm{XRD}$ pattern of the $170^{\circ} \mathrm{C}$ reaction of the quaternary mixture $\mathrm{NaAlH}_{4}: \mathrm{LiAlH}_{4}: \mathrm{MgH}_{2}: \mathrm{Cr}$

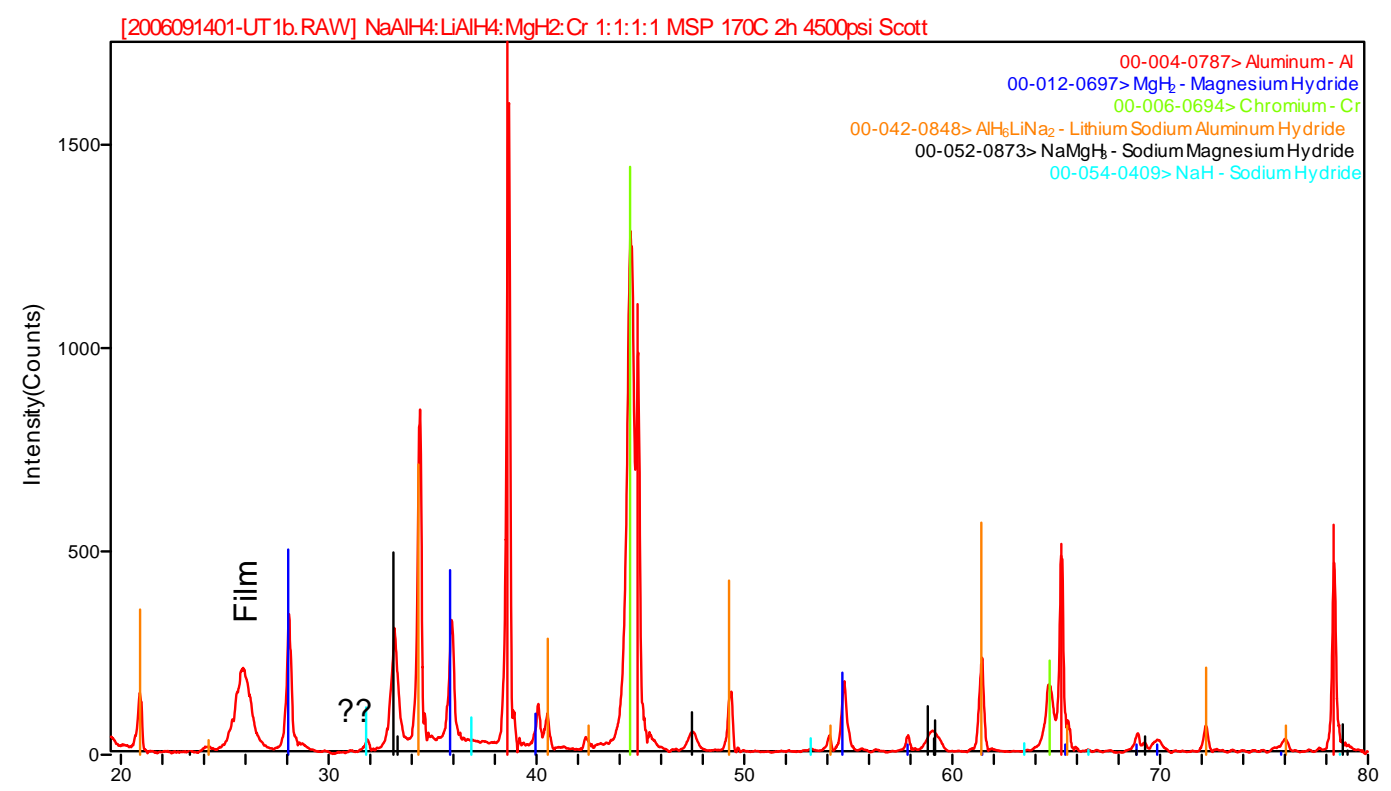

Figure 2: XRD pattern of the $170^{\circ} \mathrm{C}$ reaction of the quaternary mixture $\mathrm{NaAlH}_{4}: \mathrm{LiAlH}_{4}: \mathrm{MgH}_{2}: \mathrm{VH}_{0.81}$

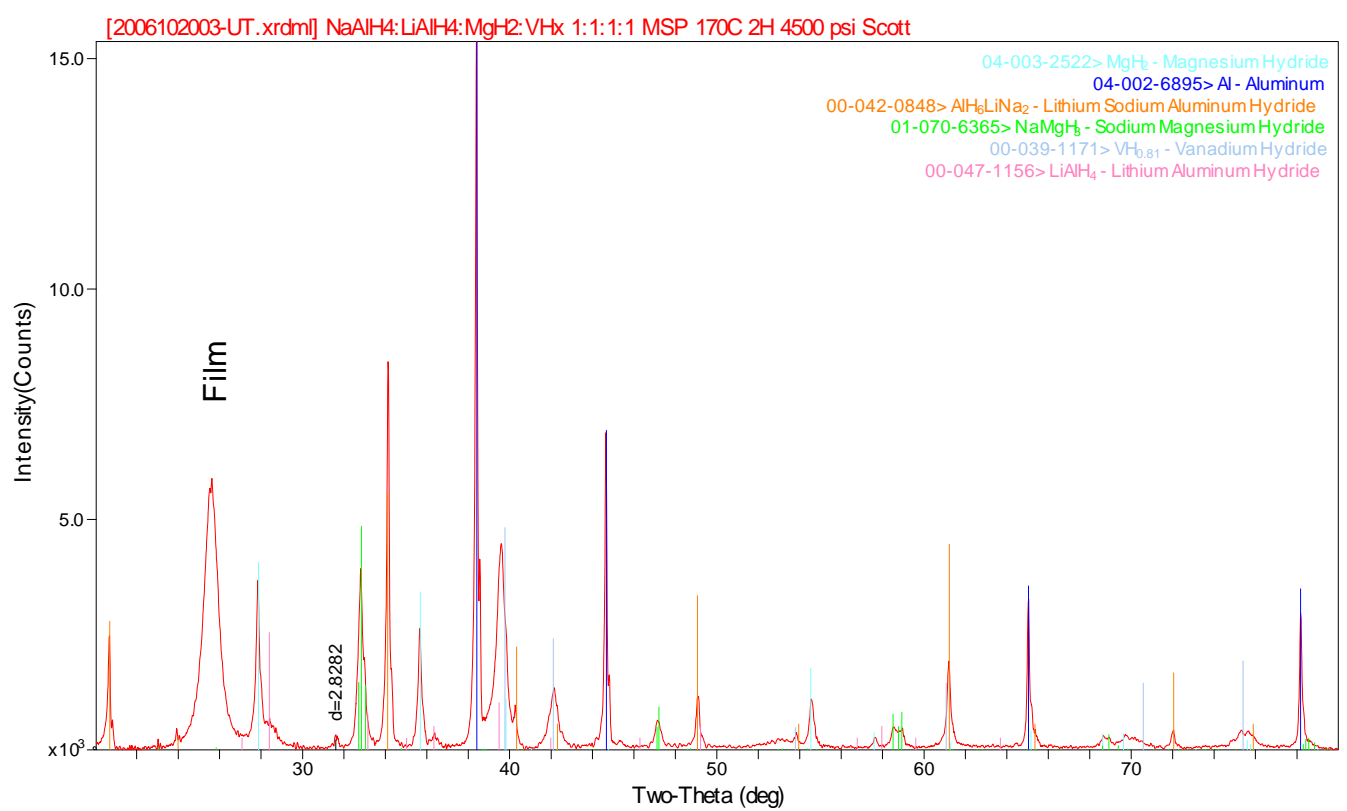

